\title{
A New and Ecological Method to Quantify Vancomycin in Pharmaceutical Product by Infrared Spectrometry
}

\author{
Patrícia Aleixa do Nascimento, ${ }^{1}$ Ana Carolina Kogawa ${ }^{1,2, *}$ \\ and Hérida Regina Nunes Salgado ${ }^{1}$ \\ ${ }^{1}$ Department of Pharmaceutics, School of Pharmaceutical Sciences of Araraquara, \\ Univ Estadual Paulista - UNESP, Araraquara, São Paulo, Brazil \\ ${ }^{2}$ Laboratório de Controle de Qualidade, Faculdade de Farmácia, Universidade Federal de Goiás - UFG, \\ Goiânia, Goiás, Brazil \\ *Corresponding author: E-mail: ac_kogawa@yahoo.com.br \\ Phone: +55 62 3209-6470
}

Received: 07-10-2020

\begin{abstract}
Vancomycin, an antimicrobial, does not present quantitative method by infrared spectrometry in the literature for the evaluation of a pharmaceutical product. This technique is considered a clean alternative because in the main, there is no solvent involved and the generation of waste is reduced. So, the aim of this study was to develop and validate a new, ecological, low cost and fast method by infrared spectrometry using $\mathrm{KBr}$ and band between $1450-1375 \mathrm{~cm}^{-1}$. It was linear in the range of $1.0-2.0 \mathrm{mg} / 150 \mathrm{mg}$, with a correlation coefficient of 0.9994 . Selective when the spectra of vancomycin reference and sample were compared. Precise by repeatability $(2.29 \%)$ and intermediate precision (3.12\%). Accurate with average recovery of $99.37 \%$ and robust when strength and compression time of the pellets and $\mathrm{KBr}$ brand were varied. Considering all the methods found in literature, there is not one using infrared spectrometry for quantitative purpose, so the method developed and validated could be considered an innovation and clean alternative. This is due to the fact that it is fast, easy to handle, low cost, and non-toxic as well as generating minimal waste. The method can be applied in the routine analysis of vancomycin dosage form and is an important option for the current and sustainable pharmaceutical analysis.
\end{abstract}

Keywords: Vancomycin; infrared spectrometric method; green analytical chemistry; sustainable alternative; pharmaceutical analysis.

\section{Introduction}

Vancomycin is the first glycopeptide antibiotic discovered. It has a molecular formula $\mathrm{C}_{66} \mathrm{H}_{75} \mathrm{Cl}_{2} \mathrm{~N}_{9} \mathrm{O}_{24}$ and molecular mass $1449.27 \mathrm{~g} \mathrm{~mol}^{-1}$. Its mechanism of action comprises the disruption of cell wall of Gram-positive bacteria, being the only antibiotic used nowadays for the treatment of infections caused by the methicillin-resistant Staphylococcus aureus (MRSA). ${ }^{1-3}$ The main nucleus in glycopeptide antibiotics is an heptapeptide, which has a different substituent depending on the antibiotic. ${ }^{4-5}$ Figure 1 shows the structure and the substituents of vancomycin.

Inhibition of the bacterial cell wall occurs when this drug binds to the final residues of D-Ala-D-Ala of peptidoglycan by van der Waals forces and five hydrogen bonds, presenting strong binding, preventing the bind of peptidoglycan. ${ }^{5-7}$

In the context of the importance of vancomycin in the drug scenario, the development of analytical methods for its evaluation becomes extremely fundamental. Some analytical methods for this drug both physico-chemi$\mathrm{cal}^{8-14}$ and microbiological were found in literature. ${ }^{15-18}$ The spectrophotometry is a kind of very useful analytical method, which provides precise results and can be applied to quantify drugs. Only seven studies were found using this technique in literature for vancomycin and all of them in the UV region. ${ }^{19-25}$ However, the spectrometry in the infrared region is also an alternative, mainly because it can also be applied in the quantitative analysis of drugs, and has already been done to other drugs. ${ }^{26-34}$ No study relat- 


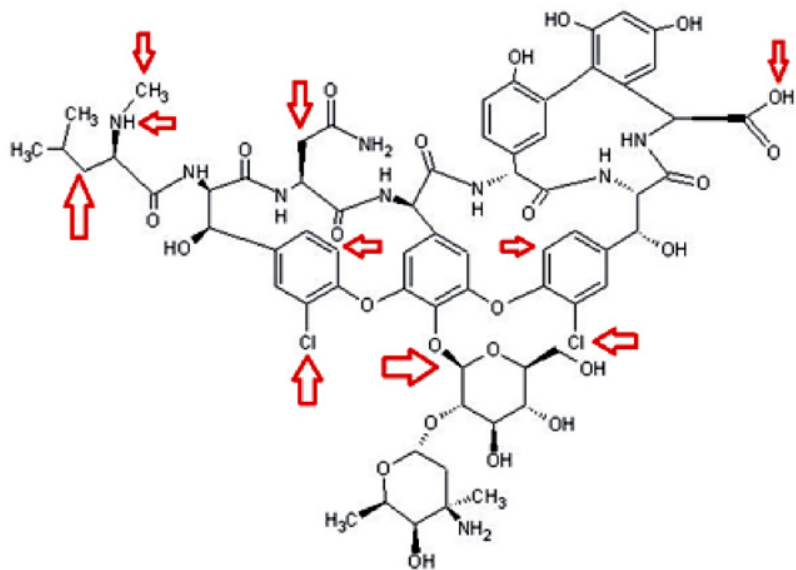

Figure 1. Structure of vancomycin with its substituents highlighted (CAS 1404-90-6).

ing this technique to vancomycin was found in literature, so the aim of this work was to develop and validate a spectrometric method in the infrared region for the quantification of vancomycin dosage form.

\section{Experimental}

\section{1. Materials and Reagentes}

Vancomycin reference (declared content 96.30\%) and lyophilized powder for injection (sample) $500 \mathrm{mg}$ (labeled content) were used in spectrometric analysis in the infrared region (IR) and they were kindly donated by the ABL Antibióticos do Brasil (Cosmópolis, São Paulo, Brazil). Potassium bromide (KBr, Neon ${ }^{\mathrm{TM}}$, Suzano, São Paulo, Brazil), previously maintained in an oven for $24 \mathrm{~h}$ before the analysis was used as diluent for pellets preparation, each pellet contained $150 \mathrm{mg}$. A pool containing vancomycin reference or sample was prepared in the ratio of 1:10 and the pellets were obtained by weighing the appropriate amount from this pool.

\section{2. Equipment}

An analytical balance DV215CD (Discovery, Ohaus $^{\circledR}$, São Paulo, Brasil) was used. An agate mortar and pestle were used to prepare the pellets, which were transferred to a compression system. A spectrophotometer IRPrestige-21 (Shimadzu ${ }^{\circledR}$, Japan) was also used and the readings were performed using the software IR Solution ${ }^{\circ}$.

\subsection{Method Development}

\subsubsection{Pellets Preparation}

Pellets of vancomycin reference and sample were prepared using $\mathrm{KBr}$ as a diluent. An amount of $20 \mathrm{mg}$ of vancomycin reference and $180 \mathrm{mg}$ of $\mathrm{KBr}$ were weighed and homogenized using the mortar and pestle. From this mixture an appropriate amount $(16 \mathrm{mg})$ was taken and added to $134 \mathrm{mg}$ of $\mathrm{KBr}$ in order to obtain $1.60 \mathrm{mg} / 150 \mathrm{mg}$ tablets. The same procedure was done to the vancomycin sample, considering the average weight from twenty vials of vancomycin (504.92 mg). An amount of $20.19 \mathrm{mg}$ vancomycin sample and $179.81 \mathrm{mg}$ of $\mathrm{KBr}$ were weighed and homogenized. Then an amount of $16 \mathrm{mg}$ was weighed and added to $134 \mathrm{mg}$ of $\mathrm{KBr}$, obtaining a final concentration of $1.60 \mathrm{mg} / 150 \mathrm{mg}$. This powder was transferred to the compression system for $7 \mathrm{~min}$ at $90 \mathrm{kN}$. After this period, pellets were placed on the spectrophotometer and the readings were performed at $1450-1375 \mathrm{~cm}^{-1}$.

\subsection{Method Validation}

\section{4. 1. Validation Parameters}

The validation procedure was performed according to the International Conference on Harmonization ${ }^{35}$ specifications for linearity, selectivity, limits of detection and quantification, precision, robustness, and accuracy.

Linearity: An analytical curve was obtained in the range of $1.00 \mathrm{mg} / 150 \mathrm{mg}$ to $2.00 \mathrm{mg} / 150 \mathrm{mg}$. For this, 99 $\mathrm{mg}$ of the vancomycin sample and $891 \mathrm{mg}$ of $\mathrm{KBr}$ was weighed and transferred to the mortar and mixed. From this pool, an appropriate amount was weighed in order to obtain pellets of $1.00,1.20,1.40,1.60,1.80$, and $2.00 \mathrm{mg} / 150 \mathrm{mg}$. The linearity assay was performed on three different days and in triplicate. The data obtained were evaluated by regression analysis. The equation of the line was determined by linear regression analysis using the method of the least squares. Analysis of Variance (ANOVA) was also performed using the absorbance values obtained for each concentration.

Selectivity: Selectivity of the method was determined by the absorbance obtained for the vancomycin reference and sample, as well as the evaluation of the overlap of their spectra.

Limits of detection and quantification: The limits of detection (LOD) and quantification (LOQ) were obtained from the three calibration curves, using the Equations 1 and 2 , respectively:

$$
\begin{aligned}
& \mathrm{LOD}=3 x \frac{S D}{a} \\
& \mathrm{LOQ}=10 x \frac{S D}{a}
\end{aligned}
$$

SD: standard deviation a: average slope

Precision: Precision was evaluated by repeatability and intermediate precision. Repeatability assay was performed using six replicates of the same concentration $(1.60 \mathrm{mg} / 150 \mathrm{mg})$ on the same day, with the same analyst, under the same conditions of analysis. Intermediate precision assay was performed by another analyst on a different day, under the same conditions of analysis. The preci- 
sion was evaluated by RSD (\%) values. The method was considered precise when RSD (\%) values were lower than $2.00 \%$.

Robustness: The robustness assay of the method was performed using $1.60 \mathrm{mg} / 150 \mathrm{mg}$ tablets and small variations in three fundamental parameters: time of compression (normal: $7 \mathrm{~min}$, variation: 5 and $9 \mathrm{~min}$ ), strength of compression (normal: $90 \mathrm{kN}$, variation: 88 and $92 \mathrm{kN}$ ) and KBr brand (normal: Neon ${ }^{\circledR}$, variation: Dinâmica ${ }^{\circledR}$ ). Each condition was analyzed in triplicate, on the same day and with the same analyst. The results were analyzed by F-test and $t$-test compared to normal conditions. The method was considered robust when $t_{\text {calculated }}$ was smaller than $t_{\text {critical }}$.

Accuracy: The accuracy of the method was demonstrated by the recovery test, in triplicate and at three levels, 80, 100 and 120\%, considering $1.60 \mathrm{mg} / 150 \mathrm{mg}$ (100\%). A standard pool was prepared with the vancomycin reference $(30 \mathrm{mg}+\mathrm{KBr}: 270 \mathrm{mg}$ ). The sample pool was also prepared under the same conditions (sample: $30.29 \mathrm{mg}+\mathrm{KBr}: 272.60 \mathrm{mg}$ ). From the reference pool an amount of $10 \mathrm{mg}$ was weighed and added to $140 \mathrm{mg}$ of $\mathrm{KBr}$, obtaining a pellet of $1.00 \mathrm{mg} / 150 \mathrm{mg}$. The same was done to the sample pool. The 3 levels, 80, 100 and 120\%, were prepared using the same amount of the sample pool (10 mg) and a different amount of the reference pool, 28, 60 and $92 \mathrm{mg}$ (equivalent to 2.80, 6.00 and $9.20 \mathrm{mg}$ ), respectively. Average recoveries, expressed in terms of percentage recovered from the standard and RSD (\%), were determined. Method was considered accurate when recovery levels were 98 to $102 \%$ and RSD (\%) values were lower than $2.00 \%$. $^{36}$

\section{5. Content Analysis}

The preparation of the pellets was carried out according to section 2.3.1. Absorbance was measured at $1450-1375 \mathrm{~cm}^{-1}$. Pellet was submitted to the compression system for 7 min under $90 \mathrm{kN}$. The values were compared using the Equation 3.

$$
\mathrm{Cs}=\mathrm{As} \times \frac{C r}{A r}
$$

Cs: concentration of sample pellet;

As: absorbance of sample pellet;

$\mathrm{Cr}$ : concentration of reference pellet;

Ar: absorbance of reference pellet.

Content measurement was considered adequate when content was $90-115 \% .^{25}$

\section{6. Comparison of Methods}

The results of the vancomycin final product content obtained using the proposed method were compared with the results obtained by a microbiological method using turbidimetry. ${ }^{37}$

\section{Results and Discussion}

\section{1. Method Development and Validation}

An appropriate amount of standard vancomycin was weighed and added to $\mathrm{KBr}$ in order to obtain pellets of

Table 1. ANOVA results for linearity of the method

\begin{tabular}{cc}
\hline Parameters & 1450-1375 $\mathbf{~ m}^{\mathbf{1}}$ \\
\hline Linearity range $(\mathrm{mg} / 150 \mathrm{mg})$ & $1.0-2.0$ \\
Slope & 0.38 \\
Intercept & 0.00 \\
Correlation coefficient $(\mathrm{r})$ & 0.99 \\
Regression & $371.33(4.75)$ \\
Lack of fit & $(3.26)$ \\
\hline
\end{tabular}

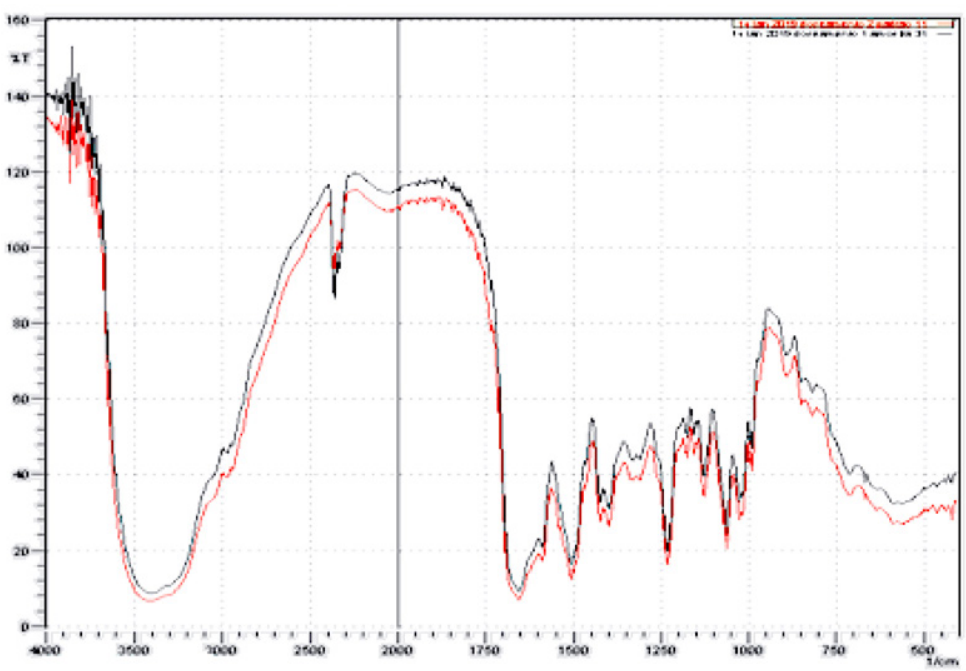

Figure 2. Overlapping spectra of vancomycin standard and sample. 
Table 2. Precision results of the method by spectrometry in the infrared region for vancomycin

\begin{tabular}{|c|c|c|c|c|c|c|c|c|}
\hline & \multirow[t]{2}{*}{ Level } & \multicolumn{6}{|c|}{ Absorbance $^{\star}$} & \multirow[t]{2}{*}{ RSD (\%) } \\
\hline & & 1 & 2 & 3 & 4 & 5 & 6 & \\
\hline \multirow{3}{*}{$1450-1375 \mathrm{~cm}^{-1}$} & Repeatability & $0.58^{a}$ & $0.60^{a}$ & $0.60^{a}$ & $0.62^{a}$ & $0.60^{a}$ & $0.59^{a}$ & 2.29 \\
\hline & Intermediate & $0.61^{b}$ & $0.62^{b}$ & $0.60^{b}$ & $0.61^{b}$ & $0.63^{b}$ & $0.62^{b}$ & 3.12 \\
\hline & & $0.63^{c}$ & $0.63^{c}$ & $0.62^{c}$ & $0.61^{c}$ & $0.66^{c}$ & $0.65^{c}$ & \\
\hline
\end{tabular}

${ }^{a}$ Absorbance obtained by analyst 1 on day $1{ }^{b}$ Absorbance obtained by analyst 1 on day $2{ }^{c}$ Absorbance obtained by analyst 2 on day $2{ }^{*}$ Six replicates

Table 3. Robustness of the method by spectrometry in the infrared region for vancomycin

\begin{tabular}{|c|c|c|c|c|c|}
\hline \multicolumn{6}{|c|}{ Parameters } \\
\hline \multirow{2}{*}{$\frac{\text { Normal condition }}{90(\mathrm{kN})}$} & \multicolumn{2}{|c|}{ Strength of compression $(\mathrm{kN})$} & \multicolumn{2}{|c|}{ Time of compression (min) } & \multirow{2}{*}{$\frac{\text { KBr brand }}{\text { Dinâmica }^{\text {ra } \star}}$} \\
\hline & $88^{\star}$ & $92^{*}$ & $5^{\star}$ & $9^{*}$ & \\
\hline $7(\min )$ & $t_{\text {critical }}=2.77$ & $t_{\text {critical }}=2.77$ & $t_{\text {critical }}=2.77$ & $t_{\text {critical }}=2.77$ & $t_{\text {critical }}=4.30$ \\
\hline Neon ${ }^{\mathrm{mm}}$ & $t_{\text {critical }}=-2.46$ & $t_{\text {critical }}=-1.27$ & $t_{\text {critical }}=-5.04$ & $t_{\text {critical }}=-0.75$ & $t_{\text {critical }}=3.98$ \\
\hline
\end{tabular}

* Three replicates

1.00-2.00 mg/150 mg. The data was validated by ANOVA (Table 1$)$, which showed significant linear regression $\left(\mathrm{F}_{\text {cal- }}\right.$ culated $\left.371.33>\mathrm{F}_{\text {critical }} 4.75, p=0.05\right)$, and no significant lack of fit $\left(\mathrm{F}_{\text {calculated }} 1.23<\mathrm{F}_{\text {critical }} 3.26, p=0.05\right)$. In this way, the method can be considered linear.

The linearity was proven by the regression analysis using the least squares method, obtaining a correlation coefficient ( $r$ ) of 0.99 . It was also proven by the Analysis of Variance (ANOVA), which showed significant linear regression and no significant lack of fit.

The selectivity of the method was analyzed by comparing the spectra of vancomycin reference (black) and sample (red) (Figure 2).

The selectivity assay of the method was performed by the overlapping spectra of vancomycin reference and sample, which identified the drug.

The LOD and LOQ obtained were, respectively, 0.01 and $0.03 \mathrm{mg} / 150 \mathrm{mg}$. The limits are low, which show the sensitivity of the method.

Precision was proven by repeatability (RSD 2.29\%) and by intermediate precision (RSD 3.12\%). Both showed adequate results of RSD (\%) and the intermediate precision was also analyzed by F-test and $t$-test, showing values of $\mathrm{F}_{\text {calculated }}<\mathrm{F}_{\text {tabulated }}(3.74<5.05)$ and $t_{\text {calculated }}<t_{\text {tabulated }}$ $(2.21<2.23)$, respectively. So, the method can be considered precise. The results for repeatability and intermediate precision are shown in Table 2.

The robustness of the method was performed by small variations in three parameters. The method can be considered robust for these varied parameters when values of test $t_{\text {calculated }}$ were smaller than the $t_{\text {critical }}$. The results are shown in Table 3.

The robustness of the method is an important parameter to be evaluated, which assures the results obtained. Variations performed in strength of compression,

Table 5. Content analysis for vancomycin reference and sample using spectrometry in the infrared region

\begin{tabular}{lccc}
\hline Day & $\begin{array}{c}\text { Average content } \\
(\mathbf{\%})^{*}\end{array}$ & $\begin{array}{c}\text { Final content } \\
(\mathbf{\%})\end{array}$ & $\begin{array}{c}\text { RSD } \\
\mathbf{( \% )}\end{array}$ \\
\hline 1 & 101.66 & & \\
2 & 101.75 & $\mathbf{1 0 2 . 3 5}$ & $\mathbf{1 . 0 9}$ \\
3 & 103.63 & & \\
\hline$*$ Three replicates & &
\end{tabular}

Table 4. Recovery results for vancomycin using the developed spectrometric method

\begin{tabular}{lccccc}
\hline & $\begin{array}{c}\text { Vancomycin } \\
\text { Standard added } \\
(\mathbf{m g} / \mathbf{1 5 0} \mathbf{~ m g})^{*}\end{array}$ & $\begin{array}{c}\text { Vancomycin } \\
\text { Standard recovered } \\
(\mathbf{m g} / \mathbf{1 5 0} \mathbf{~ m g})^{*}\end{array}$ & $\begin{array}{c}\text { Recovery } \\
\mathbf{( \% )}\end{array}$ & $\begin{array}{c}\text { recovery } \\
\mathbf{( \% )}\end{array}$ & $\begin{array}{c}\text { RSD } \\
\mathbf{( \% )}\end{array}$ \\
\hline R1 & 0.28 & 0.28 & 99.65 & & \\
R2 & 0.60 & 0.60 & 99.48 & 99.37 & 0.32 \\
R3 & 0.92 & 0.91 & 98.98 & & \\
\hline
\end{tabular}

* Three replicates 
Table 6. Comparison of methods

\begin{tabular}{lcccc}
\hline \multicolumn{1}{c}{ Method } & Average content (\%)* & Final content (\%) & RSD (\%) & Statistical evaluation \\
\hline Proposed & 101.66 & $\mathbf{1 0 2 . 3 5}$ & $\mathbf{1 . 0 9}$ & \\
(physico-chemical) & 101.75 & & & $0.32(4.30)^{* * *}$ \\
& 103.63 & & $\mathbf{4 . 9 7}$ & \\
Turbidimetric $^{* *}$ & 108.20 & $\mathbf{1 0 3 . 3 2}$ & & \\
(microbiological) & 103.81 & & & \\
\hline
\end{tabular}

${ }^{*}$ Average of 3 determinations ${ }^{* * 37}{ }^{* * *} t$-test

time of compression and $\mathrm{KBr}$ brand showed that the method remains robust and the quality of the results are reliable. This parameter is also useful in the development of other conditions for other drugs and samples, serving as a start for the conditions to be tested.

The accuracy of the developed method was determined by the standard recovery test. Recovery values are shown in Table 4, as well as the RSD (\%). The method can be considered accurate, considering the average recovery in three days of analysis, in accordance to 98$102 \%$ specified by $\mathrm{AOAC}^{36}$ and $\mathrm{RSD}(\%)$ values below $2 \%$.

\section{2. Content Analysis}

The content of vancomycin in the final product was analyzed and is shown in Table 5.

Content analysis is not a parameter required for validation but it is also important to perform because it assures the content of the drug in the marketed sample. The analysis showed that the content of vancomycin is within the limits stipulated by Japanese Pharmacopoeia (90$115 \%) .{ }^{25}$

\section{3. Comparison of Methods}

The result of the comparison between the proposed method (physico-chemical) and the turbidimetric method (microbiological) was made by the vancomycin content values in the final product and is shown in Table 6.

An antimicrobial must always be analyzed using 2 methods, 1 physico-chemical and 1 microbiological, as many times physico-chemical methods are unable to assess the real potency of the antimicrobial.

In this case, the proposed method was directly compared with the microbiological method and was statistically equivalent, which allows its reliable use in the evaluation of the vancomycin final product.

Spectrometric method in infrared region is an important technique that can be used to quantify drugs, mainly because of its ecological characteristics and simplicity to perform. It also protects the environment, due to the less generation of waste, and the analyst, who does not need to get in touch with solvents.

\section{Conclusions}

In the present work a spectrometric method in infrared region was developed for the evaluation of vancomycin in lyophilized powder. This method is by itself greener when compared to a chromatographic method or a spectrophotometric method in the UV region, because there is no use of solvents, which generates less waste, for example. It is sensitive and proven to be precise to quantify the drug, being a great alternative to the routine quality control process of vancomycin in chemical and pharmaceutical laboratories. The method is also linear in the range of 1.00 to $2.00 \mathrm{mg} / 150 \mathrm{mg}$, selective, precise, robust, and accurate. It is worth remembering that each drug has specific characteristics and specific analysis rigidities. Many times, the method of analysis of one drug is not necessarily useful for another, so this work is important, which shows the ideal and eco-frinedly conditions for the analysis of vancomycin in final product by spectrometry in infrared region. It generates less waste, does not use solvents, is fast and very simple to perform the test. Furthermore, it is advantageous because the sample can be analyzed in solid state, does not require the use of diluents or solvents, does not expose analysts to vapors that can be toxic and it can be used in production line control.

\section{Acknowledgements}

The authors acknowledge CNPq (Conselho Nacional de Desenvolvimento Científico e Tecnológico, Brasília, Brazil), FAPESP (Fundação de Amparo à Pesquisa do Estado de São Paulo, São Paulo, Brasil), CAPES (Coordenação de Aperfeiçoamento de Pessoal de Nível Superior, São Paulo, Brasil), PADC/FCF/UNESP (Programa de Apoio ao Desenvolvimento Científico/ Faculdade de Ciências Farmacêuticas/Universidade Estadual Paulista, Araraquara, Brazil) and ABL Antibióticos do Brasil.

\section{Declaration of interest}

The authors have no financial or other potential conflicts of interest. 


\section{References}

1. T. L. Smith, M. L. Pearson, K. R. Wilcox, C. Cruz, M. V. Lancaster, B. Robinson-Dunn, F. C. Tenover, M. J. Zervos, J. D. Band, E. White, W. R. Jarvis, The New England Journal of Medicine 1999, 340, 493-501.

DOI:10.1056/NEJM199902183400701

2. D. Kahne, C. Leimkuhler, W. Lu, C. Walsh, Chemical Reviews 2005, 105, 425-448. DOI:10.1021/cr030103a

3. P. M. Wright, I. B. Seiple, A. G. Myers, Angewandte Chemie International Edition England 2015, 53, 8840-8869.

DOI:10.1002/anie.201310843

4. R. Nagarajan, The Journal of Antibiotics 1993, 46, 1181-1195. DOI: 10.7164 /antibiotics.46.1181

5. H. K. Kang, P. Yoonkyung, Journal of Bacteriology and Virology 2015, 45, 67-78. DOI:10.4167/jbv.2015.45.2.67

6. K. Lazar, S. Walker, Current Opinion in Chemical Biology 2002, 6, 786-793. DOI:10.1016/S1367-5931(02)00355-1

7. D. H. Williams, B. Bardsley, Angewandte Chemie International Edition 1999, 38, 1172-1193. DOI:10.1002/(SICI)15213773(19990503)38:9<1172::AID-ANIE1172>3.0.CO;2-C

8. T. M. Lima, K. S. Seba, J. C. S. Gonçalves, F. L. L. Cardoso, C. E. Estrela, Journal of Chromatographic Science 2018, 56, 115121. DOI:10.1093/chromsci/bmx089

9. X. Song, J. Xie, M. Zhang, Y. Zhang, J. Li, Q. Huang, Journal of Chromatography B 2018, 1076, 103-109.

DOI:10.1016/j.jchromb.2018.01.020

10. A. Serri, H. R. Moghimi, A. Mahboubi, A. Zarghi, Acta Poloniae Pharmaceutica - Drug Research 2017, 74, 73-79.

11. L. Kirk, P. Lewis, Y. Luu, S. Brown, International Journal of Pharmaceutical Compouding 2016, 20, 159-163.

12. A. D. Berti, P. R. Hutson, L. T. Schulz, A. P. Webb, W. E. Rose, American Journal of Health-System Pharmacy 2015, 72, 390395. DOI:10.2146/ajhp140369

13. C. Anderson, S. Boehme, J. Ouellette, C. Stidham, M. Mackay, Hospital Pharmacy 2014, 49, 42-47. DOI:10.1310/hpj4901-42

14. P. A. Whaley, M. A. Voudrie Ii, International Journal of Pharmaceutical Compounding 2013, 16, 167-169.

15. J. J. Aguilera-Correa, A. L. Doadrio, A. Conde, M. A. Arenas, J. J. Damborenea, M. Vallet-Regí, J. Esteban, Journal of Materials Science: Materials in Medicine 2018, 29, 2-10.

DOI:10.1007/s10856-018-6119-4

16. F. L. Francisco, A. M. Saviano, T. S. B. Almeida, F. R. Lourenço, Journal of Microbiology Methods 2016, 124, 28-34. DOI:10.1016/j.mimet.2016.03.005

17. J. A. Montes, D. Johnson, J. Jorgensen, L. Mcelmeel, L. C. Fulcher, J. W. Kiel, Cornea 2016, 35, 122-126.

18. R. Gálvez-López, A. Peña-Monje, R. Antelo-Lorenzo, J. Guardia-Olmedo, J. Moliz, J. Hernández-Quero, J. Parra-Ruiz, Diagnostic Microbiology and Infectious Disease 2014, 78, 70-74. DOI:10.1097/ICO.0000000000000676

19. T. H. Hoang Thi, F. Chai, S. Leprête, N. Blanchemain, B. Martel, F. Siepmann, H. F. Hildebrand, J. Siepmann, M. P. Flament, International Journal of Pharmaceutics 2010, 400, 7485. DOI:10.1016/j.diagmicrobio.2013.09.014
20. S. Bakhshandeh, Z. G. Karaji, K. Lietaert, A. C. Fluit, C. H. E. Boel, H. C. Vogely, T. Vermonden, W. E. Hennink, H. Weinans, A. A. Zadpoor, S. A. Yavari, ACS Applied Materials and Interfaces 2017, 9, 25691-25699.

DOI:10.1016/j.ijpharm.2010.08.035

21. N. Sarkar, G. Sahoo, R. Das, G. Prusty, S. K. Swain, European Journal of Pharmaceutical Sciences 2017, 109, 359-371.

DOI:10.1021/acsami.7b04950

22. A. Esmaeili, S. Ghobadianpour, International Journal of Pharmaceutics 2016, 501, 326-330.

DOI:10.1016/j.ejps.2017.08.015

23. G. Sayet, M. Sinegre, M. Ben Reguiga, Annales Pharmaceutiques Françaises 2014, 72, 41-50.

DOI:10.1016/j.ijpharm.2016.02.013

24. L. Yongxin, J. Genlong, S. Guodong, Z. Lili, W. Shilong, L. Hanchao, L. Zhizhong, Luminescence 2014, 29, 109-117.

DOI:10.1016/j.pharma.2013.10.002

25. Japanese Pharmacopoeia. 16th E d. Tokyo Society of Japanese Pharmacopoeia, 2011.

25. P. A. Nascimento, A. C. Kogawa, H. R. N. Salgado, Austin Journal of Analytical and Pharmaceutical Chemistry 2019, 6, 1-5.

27. E. G. Tótoli, H. R. N. Salgado, Journal of AOAC International 2017, 100, 1569-1576.

28. A. H. Moreno, H. R. N. Salgado, Physical Chemistry 2012, 2, 6-11. DOI:10.5740/jaoacint.17-0067

29. B. S. Rechelo, A. C. Kogawa, H. R. N. Salgado, Spectrochimica Acta Part A: Molecular and Biomolecular Spectroscopy 2019, 208, 157-161. DOI:10.5923/j.pc.20120201.02

30. C. T. Rebouças, A. C. Kogawa, H. R. N. Salgado, Journal of AOAC International 2018, 101, 2001-2005.

DOI:10.1016/j.saa.2018.09.058

31. A. C. Kogawa, H. R. N. Salgado, Current Pharmaceutical Analysis 2018, 14, 108-115. DOI:10.5740/jaoacint.17-0431

32. A. C. Kogawa, N. P. Mello, H. R. N. Salgado, Pharmaceutica Analytica Acta 2016, 7, 463-466.

33. A. C. Kogawa, H. R. N. Salgado, Physical Chemistry 2013, 3, $1-6$.

34. M. T. Trindade, H. R. N. Salgado, Physical Chemistry 2017, 7, 55-62.

35. ICH, International Conference on Harmonization of technical requirements for registration of pharmaceuticals for human use. Validation of analytical procedures: Text and Methodology Q2(R1), https://www.ema.europa.eu/en/documents/ scientific-guideline/ich-q-2-r1-validation-analytical-procedures-text-methodology-step-5_en.pdf (assessed: April 28, 2020)

36. AOAC, Association of Official Analytical Chemists. Official Methods of Analysis, http://members.aoac.org/aoac_prod_ imis/AOAC_Docs/StandardsDevelopment/SLV_Guidelines_ Dietary_Supplements.pdf (assessed: April 28, 2020)

37. P. A. Nascimento, A. C. Kogawa, H. R. N. Salgado, Journal of AOAC International 2020, 103, 1582-1587.

DOI:10.1093/jaoacint/qsaa068 


\section{Povzetek}

Za določanje protimikrobne učinkovine vankomicina $\mathrm{v}$ farmacevtskih proizvodih $\mathrm{v}$ literaturi ni najti kvantitativne metode $\mathrm{z}$ infrardečo spektrometrijo. Ta tehnika se smatra za čistejšo alternativo, saj v splošnem ne uporablja nobenih topil in je tudi količina odpadkov zmanjšana. Cilj te raziskave je bil razviti in validirati novo ekološko, poceni in hitro metodo $\mathrm{z}$ infrardečo spectrometrijo $\mathrm{z}$ uporabo $\mathrm{KBr}$ in traka $1450-1375 \mathrm{~cm}^{-1}$. Metoda je bila linearna $v$ območju $1,0-2,0 \mathrm{mg} / 150 \mathrm{mg}$ s korelacijskim koeficientom 0,9994 . Selektivna ob primerjavi spektra referenčnega vankomicina in vzorca. Natančna s ponovljivostjo $2,29 \%$ in vmesno ponovljivostjo $3,12 \%$. Točna s povprečnim izkoristkom $99,37 \%$ ter robustna, če smo spreminjali moč in čas kompresije peletov ter znamko $\mathrm{KBr}$. Ob primerjavi z metodami v literaturi ni nobene, ki bi uporabljala infrardečo spektrometrijo za kvantitativne namene, zato predstavljeno validirano metodo lahko smatramo za inovacijo in čistejšo alternativo. Razlog je, da je hitra, enostavna za uporabo, poceni, nestrupena ter proizvaja minimalno odpadkov. Metodo se lahko uporabi za rutinsko analizo vankomicina v farmacevtskem prašku in predstavlja pomembno možnost za sodobno in trajnostno farmacevtsko analitiko. 